\title{
Granulated asphalt mix based on industrial and domestic waste
}

\author{
Alexey Ignatiev ${ }^{1, *}$, Denis Gerasimov ${ }^{1, *}$, Igor Golikov ${ }^{2}$, and Valeriy Gotovtsev ${ }^{3}$ \\ ${ }^{1}$ Yaroslavl State Technical University, Department of hydraulic engineering and road construction, \\ 150023, Yaroslavl, 88 Moskovsky avenue, Russian Federation \\ ${ }^{2}$ Yaroslavl State Technical University, Department of Chemical Technology of Organic Coatings, \\ 150023, Yaroslavl, 88 Moskovsky avenue, Russian Federation \\ ${ }^{3}$ Yaroslavl State Technical University, Department of Enterprise Management, \\ 150023, Yaroslavl, 88 Moskovsky avenue, Russian Federation
}

\begin{abstract}
The paper presents the results of experimental studies to identify the possibility of using large-tonnage industrial mineral waste in the production of asphalt concrete mixtures. As a raw material for the production of asphalt used phosphogypsum - waste production of phosphoric acid, resulting from the processing of apatite. The reserves of this product are measured in millions of tons and are constantly replenished, stored in open dumps, representing a serious threat to the environmental situation in the surrounding areas. Phosphogypsum is a mineral powder material, the dispersion characteristics of which correspond to the mineral powder in the production of asphalt concrete. The method of production of granulated as-falto-concrete mixture developed by the authors of the article by the method of rolling involves the use of a significantly higher content of expensive mineral powder in comparison with typical mixtures. Therefore, the use of cheap phosphogypsum for these purposes is very attractive. However, the first attempts to obtain a granulated product based on phosphogypsum were unsuccessful - the asphalt-concrete mixture did not withstand the effects of moisture. Further studies allowed us to solve the problem of material resistance by modifying bitumen with polyethylene terephthalate, one of the most common household plastic waste. The subject of the article is devoted to the development of prescription and regime parameters of the process of obtaining new material. Test methods for asphalt concrete are strictly standardized in connection with which standard techniques were used. As a result of the research, an asphalt-concrete mixture was obtained, surpassing typical materials in many performance characteristics and allowing to solve a global environmental problem.
\end{abstract}

\section{Introduction}

The problem of utilization of industrial and household waste with the development of society is becoming increasingly important. On the one hand, natural resources are

* Corresponding author: ignatyevaa@ystu.ru; geras930@mail.ru 
decreasing, on the other hand, the amount of industrial and household waste is growing. According to the standard reference book ITS 15-2016, the annual volume of production and consumption waste in the Russian Federation is more than 5 billion tons. Existing technologies for utilization of industrial and household waste are not able to process annually increasing volumes, which threatens with a global environmental disaster. In line with this, any proposals for waste disposal are becoming increasingly relevant. The purpose of this publication is to introduce the technology of utilization of phosphogypsum a waste of phosphoric acid production during the processing of apatite. The volume of this waste amounts to millions of tons, stored in dumps near processing plants. Recycling of industrial waste of this scale should satisfy a whole set of requirements. The material obtained as a result of waste disposal must have a set of consumer properties that guarantee its practical use. Taking into account the accumulated volume of waste, the rate of disposal should be comparable to the volume of newly received waste. In addition, the material for recycling waste must have a sufficiently long period of preservation of operational performance, allowing you to harvest it "for future use" and use it as needed. One of the most promising areas for the use of large-capacity industrial waste is, in our opinion, road construction. The volumes of materials required for a breakthrough in this area, taking into account the current state of the road network of the Russian Federation, are enormous, which can guarantee the relevance of the waste product.

The purpose of this work is to develop a production technology for granulated asphalt concrete mix [1], in which phosphogypsum plays the role of a mineral powder. Granulated asphalt concrete mixture, obtained by the method of rolling, allows to obtain an ordered structure of the material, ensuring the strength and durability of the asphalt concrete pavement [2]. Granular material does not show a tendency to caking and can be stored for a long time without loss of performance properties. A key component of the material is mineral powder - one of the most expensive mineral components of the asphalt mix. Its replacement in the framework of the technology under consideration with cheaper material could have a tangible economic effect.

Phosphogypsum is a large-tonnage waste from the production of mineral fertilizers resulting from the processing of apatite concentrate using sulfuric acid technology. Full utilization of phosphogypsum is practically excluded, due to the strongly acidic reaction, contamination by phosphoric fluoride and other compounds. The impossibility of using phosphogypsum leads to its forced accumulation in dumps, the volumes of which are measured, as a rule, in millions of tons. Environmental pollution by various chemical compounds causes their accumulation in surface and soil waters and in crops [3]. The problem of the utilization of phosphogypsum in our country has not yet been solved [4-13] due to the lack of the necessary technical solutions. The volumes of waste dumps continue to grow, which inevitably leads to an environmental catastrophe. The use of granulated asphalt mix with phosphogypsum instead of mineral powder will allow to obtain a highstrength and durable pavement material, the need for which in our country is enormous. The basis for the use of phosphogypsum as a mineral powder of asphalt-concrete mixture is its dispersion composition. This powdered product has a specific surface comparable to the specific surface of the mineral powder used in the production of asphalt concrete mixtures. Thus, in the production technology, operations associated with the grinding of the material are excluded.

\section{Methods}

The choice of research method is due to the specifics of the material obtained from the product to be disposed of. In our case, such a product is asphalt concrete, the properties of which are strictly regulated by the requirements of the standards. In accordance with this 
question about the choice of research methodology was not - the asphalt concrete mix tests were carried out according to the standard method in accordance with GOST 12801-98. The preparation of granulated asphalt mix was carried out in a heated drum granulator, in which pre-calculated portions of mineral powder and binder were alternately introduced. Further, the evaluation of the properties of the asphalt mix was carried out in accordance with the standard, i.e. Asphalt concrete samples were molded and tested on standard equipment. The research process can be presented in three stages. At the first stage, the possibility of obtaining asphalt-concrete mixture based on phosphogypsum was determined in accordance with the technological parameters stated in the patent [1]. As a result, a granulated asphalt-concrete mixture was obtained, the tests of which gave an encouraging result. The strength of asphalt concrete from such a mixture was more than twice the requirements of GOST. However, water resistance tests showed that the material does not withstand moisture and crumbles after several days in water. The second stage of research consisted in the search for a bitumen modifier ensuring the water resistance of the asphalt concrete obtained. Various types of plastic were used as additives, as a result of which it was found that polyethylene terephthalate (PET) is the most suitable material for this purpose - the material from which a significant portion of household plastic containers are made and whose waste, if used incorrectly, represents a serious environmental problem. The third stage of research consisted in determining the optimal parameters of the technological process of producing granulated asphalt concrete mixture based on phosphogypsum using PET as a modifier of bitumen.

\section{Results}

Granulated asphalt concrete mixture on phosphogypsum as a mineral powder made it possible to obtain samples of asphalt concrete with an indicator of compressive strength at $20^{\circ} \mathrm{C}-5.3 \mathrm{MPa}$, which is more than twice the requirements of the standard. Figure 1 shows a photograph of a granulated asphalt mix.

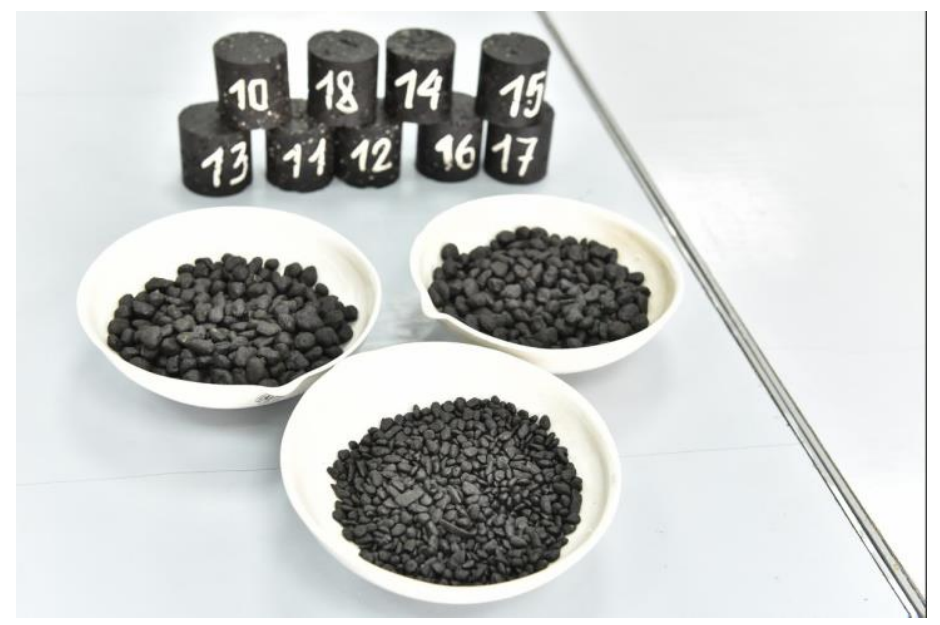

Fig. 1. Granulated asphalt concrete mixture.

Granulated asphalt mixture is a set of granules that in the cold state do not show a tendency to caking, this positive point contributes to long-term storage without loss of performance. This property of the material distinguishes it from most types of cold asphalt 
mixes, which lose their characteristics over time or require special storage conditions. From an economic point of view, the ability to long-term storage allows you to procure material into the well in unlimited quantities and use it as needed.

Table 1. The results of studies of granulated material

\begin{tabular}{|c|c|c|c|c|c|}
\hline \multirow{2}{*}{$\begin{array}{c}\text { Name } \\
\text { indicators }\end{array}$} & \multicolumn{2}{|c|}{ Phosphogypsum } & \multicolumn{2}{c|}{ Mineral powder MP-1 } & Requirements of \\
\cline { 2 - 5 } & $T=130{ }^{\circ} \mathrm{C}$ & $T=20{ }^{\circ} \mathrm{C}$ & $T=130{ }^{\circ} \mathrm{C}$ & $T=20{ }^{\circ} \mathrm{C}$ & $\begin{array}{c}\text { GOST 9128- } \\
2013\end{array}$ \\
\hline Water saturation, \% & 0.60 & 0.95 & 0.19 & 0.29 & $1.00-2.50$ \\
\hline $\begin{array}{c}\text { Compressive } \\
\text { strength, MPa }\end{array}$ & 5.30 & 3.80 & 4.67 & 4.06 & Not lees 2.50 \\
\hline $\begin{array}{c}\text { Coefficient of water } \\
\text { resistance }\end{array}$ & 1.25 & 1.29 & 1.35 & 1.48 & 0.95 \\
\hline $\begin{array}{c}\text { Long-term water } \\
\text { saturation, \% }\end{array}$ & 4.60 & 4.02 & 1.05 & 1.30 & Not standart \\
\hline $\begin{array}{c}\text { Coefficient of water } \\
\text { resistance at } \\
\text { Duration water } \\
\text { saturation. }\end{array}$ & 1.06 & 1.09 & 1.12 & 1.15 & 0.95 \\
\hline
\end{tabular}

Table 1 presents the results of studies of granulated material obtained by rounding particles of granite crushed stone of a fraction of 5-10 $\mathrm{mm}$ with an asphalt-bonding agent shell from phosphogypsum on modified PET bitumen. The content of phosphogypsum was $20 \%$ by weight of the mineral part of the mixture, the binder content was $6.2 \%$ by weight of the mixture, the PET content was $50 \%$ by weight of the binder.The purpose of the test was: to determine the possibility of creating a waterproof material based on phosphogypsum; compliance with the requirements of GOST; comparing the values of indicators of samples on phosphogypsum with samples on the mineral powder MP-1; identifying the possibility of laying the material in a cold state - samples of asphalt concrete were molded in a hot state at a temperature of $130{ }^{\circ} \mathrm{C}$ and a cold state at room temperature. As follows from the table, all tested samples have high resistance to water - the value of the coefficient of resistance is determined by the ratio of the strength of a water-saturated sample to that of a dry sample. An indicator of water resistance with a value greater than one indicates even the hardening of the material under the influence of moisture. Cold strength specimens are lower than hot specimens, but significantly exceed the requirements of GOST for cold mixes.

Table 2. The results of studies to determine the optimal content of PET in bitumen

\begin{tabular}{|c|c|c|c|c|c|}
\hline \multirow{2}{*}{$\begin{array}{c}\text { Name } \\
\text { indicators }\end{array}$} & \multicolumn{5}{|c|}{ Content of plastic, \% } \\
\cline { 2 - 6 } & 0 & 10 & 20 & 30 & 40 \\
\hline Water saturation, \% & 8.60 & 1.83 & 1.69 & 1.53 & 1.01 \\
\hline Compressive strength, MPa & 8.47 & 8.79 & 8.97 & 10.07 & 10.87 \\
\hline Coefficient of water resistance & 0.31 & 1.23 & 1.30 & 1.32 & 1.32 \\
\hline Long-term water saturation, \% & 30.60 & 4.06 & 1.52 & 3.44 & 3.07 \\
\hline $\begin{array}{c}\text { Coefficient of water resistance } \\
\text { at Duration water saturation. }\end{array}$ & 0.21 & 0.92 & 0.93 & 0.93 & 0.96 \\
\hline
\end{tabular}

Table 2 shows the results of studies to determine the optimal content of PET in bitumen. Asphalt mixture was a granulated asphalt binder containing phosphogypsum and modified bitumen with different PET contents. The content of the binder in the material was $18 \%$ by weight of the mixture. Compression of asphalt concrete samples was carried out at a temperature of $130{ }^{\circ} \mathrm{C}$, granulation at a temperature of $150{ }^{\circ} \mathrm{C}$. As follows from the table of 
data, the strength indicators of the material from asphalt binder are significantly higher than those for asphalt concrete mixture containing particles of crushed stone. This effect confirms the hypothesis of P.A. Rebinder that the strength of the composite is determined to a greater extent by the strength of the bonds in the matrices This effect confirms the hypothesis of P.A. Rebinder that the strength of the composite is determined to a greater extent by the strength of the bonds in the matrix of the material than by the strength of the filler forming its framework [14]. The results show that even a minor addition of PET to bitumen at the level of 10-20\% brings the value of the coefficient of water resistance to the required standard. Increased strength with high contents of plastic in the binder are not, as a rule, the advantage of the material. Usually, an increase in strength leads to brittleness of the material and requires the introduction of a plasticizer into the asphalt concrete mix. However, research in this direction has not been conducted.

Table 3. The results of testing the asphalt-concrete mixture as a function of the granulation temperature of the material

\begin{tabular}{|c|c|c|c|c|c|c|}
\hline \multirow{2}{*}{$\begin{array}{c}\text { Name } \\
\text { indicators }\end{array}$} & \multicolumn{5}{|c|}{ Granulation temperature $T_{\text {gr }},{ }^{0} \mathrm{C}$} \\
\cline { 2 - 7 } & \multicolumn{2}{|c|}{$100{ }^{0} \mathrm{C}$} & \multicolumn{2}{c|}{$130{ }^{0} \mathrm{C}$} & & 0.23 \\
\hline Water saturation, \% & 0.88 & 0.27 & 0.52 & 0.45 & 0.18 \\
\hline $\begin{array}{c}\text { Compressive } \\
\text { strength, MPa }\end{array}$ & 5.09 & 5.20 & 5.62 & 5.92 & 6.10 & 5.97 \\
\hline $\begin{array}{c}\text { Coefficient of water } \\
\text { resistance }\end{array}$ & 1.03 & 1.12 & 1.09 & 1.13 & 1.32 & 1.13 \\
\hline $\begin{array}{c}\text { Long-term water } \\
\text { saturation, \% }\end{array}$ & 1.94 & 1.37 & 1.32 & 1.30 & 3.07 & 1.06 \\
\hline $\begin{array}{c}\text { Coefficient of water } \\
\text { resistance at } \\
\text { Duration water } \\
\text { saturation. }\end{array}$ & 0.92 & 1.02 & 0.94 & 1.06 & 0.96 & 1.07 \\
\hline
\end{tabular}

Table 3 shows the results of testing the asphalt-concrete mixture as a function of the granulation temperature of the material. The need for testing of this kind is due to a paradoxical, at first glance, situation. The melting point of polyethylene terephthalate is $250{ }^{\circ} \mathrm{C}$, while the data given in the previous tables were obtained by granulation at a temperature of $150{ }^{0} \mathrm{C}$. This interesting effect certainly requires additional research. According to the data in the table, we can conclude that the preparation of asphalt concrete mixture by the proposed method becomes possible even at lower temperatures than is provided for by the requirements of the standard. Unfortunately, the mechanism of this phenomenon remains unclear. In the literature there are fragmentary data on this effect, but the rationale is not given [15-16].

\section{Discussion}

The developed technology for obtaining granulated asphalt-concrete mixture based on phosphogypsum wastes allowed to obtain a material with increased strength and water resistance. Thus, this material can compete with existing types of asphalt mixes. Unlike most materials used, the product is capable of long-term storage without loss of performance, allows the possibility of laying in the roadway, both hot and cold.

The use of technology can fundamentally solve the problem of utilization of phosphogypsum and other powdered industrial waste, as well as household plastic waste. 
Volumes of products are not limited to short-term needs, allow the preparation of "for the future" with further use as needed.

The production technology does not require the use of unique equipment, and can be equipped with mass-produced units.

We express our gratitude to all the colleagues who supported us while working on the article.

\section{References}

1. Patent RF № 2182136. Sposob polucheniya asfaltobetonnoy smesi. 10.05.2002.

2. A.A. Ignatiev, D.V. Gerasimov, I.V. Golikov, V.M. Gotovtsev. Dispersed-filled composites with a structured nanoscale. IOP Conference Series: Materials Science and Engineering. Vol. 365, (2018). - Article ID 032064 - doi:10.1088/1757899X/365/3/032064.

3. M.G. Iglenkova / Vzaimosvyaz fiziko-khimicheskikh i ekspluatatsionnykh parametrov kompozitov na osnove fosfogipsa/ M.G. Iglenkova. A.A. Rodina. V.A.Reshetov. S.B. Romadenkina // Izvestiya Saratovskogo universiteta. Novaya seriya. Ser.: Khimiya. Biologiya. Ekologiya, Vol. 12, (2012), P. 45-47.

4. A.S.Egorkin / Informatsionnaya sistema dlya resheniya problemy utilizatsii otkhodov fosfornoy promyshlennosti / A.S. Egorkin, E.M. Koltsova, G.N. Semenov // Uspekhi v khimii i khimicheskoy tekhnologii. Vol. 25, (2011), P. 27-31.

5. A.I. Shuyskiy / Metody i sposoby pererabotki fosfogipsa v kondi-tsionnoye syrye $\mathrm{s}$ uchetom ekologicheskikh faktorov /A.I. Shuyskiy, A.A. Novozhilov, E.A. Torlina // Ekonomika i ekologiya territorialnykh obrazovaniy. No. 1, (2016), P. 82-84.

6. D.A. Nikonova / Ekonomicheskaya otsenka proyekta kompleksnoy perera-botki fosfogipsa $\mathrm{s}$ poputnym izvlecheniyem redkozemelnykh elementov na osnove ispolzovaniya metodiki «Zatraty-Vygody» // Internet-zhurnal «Naukovedeniye». Vol. 9, No. 6, (2017), P. 1-12.

7. V.M. Sizyakov / Tekhnologiya kompleksnoy pererabotki fosfogipsa konversionnym sposobom s polucheniyem sulfata ammoniya fosfomela i novykh produktov / V.M. Sizyakov, S.V. Nutrikhina, B.V. Levin // Zapiski Gornogo instituta. Vol. 197, (2012), P. 239-244.

8. S.P. Kochetkov / Sovremennyye ekologicheskiye tendentsii v tekhnologii pererabotki prirodnykh fosfatov / S.P. Kochetkov, S.V. Bryl, G.V. Rukhlin // Sistemnyye tekhnologii. No. 19, (2016), P.115-121.

9. S.N. Zolotukhin / Vliyaniye tolshchiny vodnykh plenok na strukturu kompozitsionnogo stroitelnogo materiala $\mathrm{s}$ ispolzovaniye fosfogipsa / S.N. Zolotukhin. O.B. Kukina, A.A. Abramenko, A.A. Gapeyev, E.A. Solovyeva, E.A. Savenkova // Vestnik VGTU. Vol. 13, No. 2, (2017), P. 138-143.

10. A.M. Kasimov / Utilizatsiya fosfogipsa s polucheniyem materiala dlya proizvodstva gipsovykh vyazhushchikh / A.M. Kasimov, O.E. Leonova, V.P. Minyaylo. // Ekologiya i promyshlennost. No. 1, (2007), P. 24-27.

11. E.A. Udalova / Sovremennoye sostoyaniye i perspektivnyye vozmozhnosti ispolzovaniya fosfogipsa dlya proizvodstva vyazhushchikh materialov / E.A. Udvalova, A.I. Gabitov, A.R. Shuvayeva, I.V. Nedoseko, A.R. Chernova, V.V. Yamilova // Istoriya nauki i tekhniki. Istoriya i pedagogika estestvoznaniya. Vol. 4, (2016), P. 55-57.

12. N.A. Shamadinova / Tsementy nizkotemperatrunogo obzhiga na osnove promyshlennykh otkhodov / N.E. Shamadinova, Kh.A. Adinayev, T.A. Atakuziyev // Universum: Tekhnicheskiye nauki: elektron. nauchn. Zhurn. No. 1, (2018). 
13. T.A. Atakuziyev / Issledovaniya formirovaniya sulfomineralov sulfatosoderzhashchikh klinkerov na osnove gipsa i fosfogipsa / T.A. Atakuziyev, N.E. Shamadinova, Kh.A. Adinayev // Khimicheskaya promyshlennost. No. 3, (2017), P. 114-120.

14. P.A.Rebinder. Izbrannyye trudy. Poverkhnostnyye yavleniya v dispersnykh sistemakh. Ch. Fiziko-khimicheskaya mekhanika. - Moscow.: Nauka. 1979. - 469 p.

15. Ya.N. Kovalev / Modifikatsiya bituma polietilenovoy obolochkoy i tekhnologiya proizvodstva asfaltobetona na ego osnove / Ya.N. Kovalev, V.N. Romanyuk // Vestnik kharkovskogo natsionalnogo avtomobilno-dorozhnogo universiteta. No. 40, (2008), P. 45-47.

16. Ya.N. Kovalev / Kapsulirovaniye bituma khimicheski sovmestimoy polimernoy dobavkoy. svoystva modifitsirovannogo vyazhushchego i asfaltobetona na ego osnove / Ya.N. Kovalev, V.N. Romanyuk // Nauka i tekhnika v dorozhnoy otrasli. No. 1, (2007), P. 29-31. 